\title{
A LISTA SUJA COMO INSTRUMENTO EFICIENTE PARA REPRIMIR A EXPLORAÇÃO DE MÃO DE OBRA EM CONDIÇÕES SEMELHANTES À ESCRAVIDÃO
}

\author{
LA LISTA SUJA COMO INSTRUMENTO EFICAZ PARA REPRIMIR LA \\ EXPLOTACIÓN LABORAL EN CONDICIONES SIMILARES A LA ESCLAVITUD
}

\author{
${ }^{1}$ Maria da Conceição Maia Pereira
}

\section{RESUMO}

Com a assinatura da Lei Áurea em 1888, o Brasil foi o último país da América Latina a abolir a escravidão. Apesar disso, a utilização de mão de obra em condições análogas à de escravo perdura até os dias atuais, tanto que, em 1995, o Estado brasileiro reconheceu oficialmente sua responsabilidade pela existência dessa chaga social e se comprometeu a julgar e punir os que fazem uso de tal prática, bem como adotar medidas para erradicá-la e preveni-la. Dentre os vários instrumentos utilizados pelo Governo brasileiro para reprimir a exploração de mão de obra em condições semelhantes à escravidão em território nacional, que atenta contra a dignidade da pessoa humana, tem-se o Cadastro de Empregadores flagrados mantendo trabalhadores em condições análogas à de escravo, a chamada lista suja. Instituída por meio de portaria do Ministério do Trabalho e Emprego, contra a qual houve o ajuizamento de Ação Direta de Inconstitucionalidade no Supremo Tribunal Federal, a lista suja revela à sociedade, com base na Lei de Acesso à Informação, os empregadores que ainda praticam o trabalho escravo contemporâneo. Nesse contexto, o presente artigo busca abordar a questão da existência de trabalho em condições análogas à de escravo em pleno século XXI, apresentando o conceito de tão odiosa prática, quais as medidas tomadas pelo governo para extirpar e combater a escravidão contemporânea no país e, de maneira específica, analisar a eficácia e sustentar a manutenção da lista suja. Para tal objetivo, a metodologia adotada será a pesquisa bibliográfica.

Palavras-chave: Palavras-chave: trabalho escravo, Cadastro de empregadores ou lista suja, Políticas públicas, Dignidade da pessoa humana

\footnotetext{
${ }^{1}$ Especialização em Direito Social pelo Centro Universitário Newton Paiva - CNP, Minas Gerais (Brasil). E-mail: mcmaiap@yahoo.com.br
} 


\section{RESUMEN}

Con la firma de la Lei Áurea en 1888, Brasil fue el último país de América Latina en abolir la esclavitud. Sin embargo, el uso de mano de obra en condiciones análogas a la esclavitud perdura hasta nuestros días. Tanto es así que, en 1995, el gobierno de Brasil reconoció oficialmente su responsabilidad en la existencia de esta llaga social y se comprometió a juzgar y punir a los que utilizan de tal práctica y adoptar medidas para erradicarla y prevenirla. Entre los diversos instrumentos utilizados por el gobierno brasileño para reprimir la explotación laboral en condiciones similares a la esclavitud en su territorio, lo que atenta contra la dignidad de la persona humana, hay el Registro de Empleadores atrapados por mantener los trabajadores en condiciones similares a la esclavitud, la llamada lista suja (N.T.: lista sucia, en español). Establecida por un decreto del Ministerio de Trabajo y Empleo, contra la cual hubo la presentación de la Acción Directa de Inconstitucionalidad ante la Corte Suprema, la lista suja revela a la sociedad, basado en la Ley de Acceso a la Información, los empleadores que todavía practican la esclavitud contemporánea. En este contexto, este artículo trata de abordar la cuestión de la existencia de trabajo en condiciones análogas a la esclavitud en el siglo XXI, presentando el concepto de práctica tan odiosa, cuales son las medidas adoptadas por el gobierno para erradicar y combatir la esclavitud contemporánea en el país y, en concreto, analizar la efectividad y sostener el mantenimiento de la "lista suja". Con este objetivo, la metodología adoptada será la investigación bibliográfica.

Palabras-claves: trabajo esclavo, Registro de los empleadores o "lista suja", Políticas públicas, La dignidad de la persona humana 


\section{INTRODUÇÃO}

O Brasil, em 1957, ratificou a Convenção 29 da Organização Internacional do Trabalho (OIT), que define "trabalho forçado ou obrigatório". Em 1965, também foi ratificada pelo Estado brasileiro a Convenção 105 da OIT, por meio da qual todo país-membro do referido Organismo internacional se compromete a abolir toda forma de trabalho forçado ou obrigatório e dele não fazer uso.

Foram também ratificadas pelo Brasil, em 1966, a Convenção das Nações Unidas sobre Escravatura de 1926, emendada pelo Protocolo de 1953, e a Convenção Suplementar sobre a Abolição da Escravatura de 1956, por meio das quais seus signatários se comprometeram a abolir integralmente todas as formas de escravidão.

Por sua vez, a atual Carta Magna, promulgada em 05.10.1988, fixa, como princípios fundamentais da República Federativa do Brasil, a dignidade da pessoa humana e os valores sociais do trabalho (artigo $1^{\circ}$, III e IV) e estabelece que a ordem econômica, fundada na valorização do trabalho humano e na livre iniciativa, tem por fim assegurar a todos existência digna (artigo 170, caput).

Em 1992 o Brasil ainda ratificou o Pacto Internacional de Direitos Civis e Políticos das Nações Unidas de 1966, que, em seu artigo 8, proíbe todas as formas de escravidão, e a Convenção Americana sobre Direitos Humanos (Pacto de São José da Costa Rica) de 1969, que impôs aos signatários o compromisso de reprimir a servidão e a escravidão em todas as suas formas.

Nada disso, entretanto, impediu que o Brasil fosse denunciado, em 1994, à Comissão Interamericana de Direitos Humanos (CIDH), órgão da Organização dos Estados Americanos (OEA), no caso intitulado "Zé Pereira", por não cumprir com sua obrigação de proteger os direitos humanos.

O caso "Zé Pereira" revelou ao mundo que o trabalhador rural José Pereira Ferreira, em 1989, com 17 anos de idade, fugiu da Fazenda Espírito Santo, na cidade de Sapucaia, no sul do Pará, onde trabalhava em condições análogas à de escravo e, em decorrência, sofreu:

[...] uma emboscada preparada pelo "gato" e outros três funcionários da fazenda, que lhe deram um tiro na cabeça pelas costas.

Sangrando, Pereira fingiu-se de morto e foi jogado em uma fazenda vizinha junto com seu companheiro de fuga, o Paraná, morto na mesma emboscada pelos jagunços. Atingido em um dos olhos, caminhou até a sede da propriedade e pediu socorro. Em Belém, capital do estado, o ex-escravo denunciou as condições de trabalho na 
fazenda à Polícia Federal. Sem resposta efetiva das autoridades, levou o caso às ONGs, que decidiram apresentar a denúncia à OEA. ${ }^{1}$

Prestes a sofrer sanção internacional por conta da denúncia apresentada à OEA, em 1995, o Brasil reconheceu oficialmente sua responsabilidade pela existência de trabalho em condições análogas à de escravo no país e se comprometeu a julgar e punir os que fazem uso de tão nefasta prática, bem como adotar medidas para erradicá-la e preveni-la.

Com o fito de cumprir as exigências estabelecidas no Acordo de Solução Amistosa firmado com a CIDH, o Governo Brasileiro, criou, em 1995, o Grupo Executivo de Repressão ao Trabalho Forçado (GERTRAF) e o Grupo Especial de Fiscalização Móvel (GEFM).

Em julho de 2003, o GERTRAF foi substituído pela Comissão Nacional de Erradicação do Trabalho Escravo (CONATRAE), que tem como principal função monitorar a execução do Plano Nacional para Erradicação do Trabalho Escravo.

No pacto celebrado o Estado brasileiro ainda se comprometeu a reparar os danos causados ao trabalhador rural José Pereira Ferreira. Assim, em 2003, o Brasil pagou a primeira indenização a um cidadão brasileiro que laborou em condições análogas à de escravo. Tal reparação foi estabelecida no artigo $1^{\text {o }}$ da Lei 10.706 , de 31.07 .2003 , redigido nos seguintes termos:

Art. $1^{\circ}$ Fica a União autorizada a conceder indenização de $\mathrm{R} \$ 52.000,00$ (cinquenta e dois mil reais) a José Pereira Ferreira, portador da carteira de identidade RG $\mathrm{n}^{\circ}$ 4.895.783 e inscrito no CPF sob o $\mathrm{n}^{\mathrm{o}} 779.604 .242-68$, por haver sido submetido à condição análoga à de escravo e haver sofrido lesões corporais, na fazenda denominada Espírito Santo, localizada no Sul do Estado do Pará, em setembro de $1989 .^{2}$

Também em 2003 houve o lançamento, pelo Presidente da República, do $1^{\circ}$ Plano Nacional para a Erradicação do Trabalho Escravo, elaborado pela Comissão Especial do Conselho de Defesa dos Direitos da Pessoa Humana (CDDPH).

Ainda em 2003, o Congresso Nacional aprovou a Lei 10.803, que alterou a redação do artigo 149 do Código Penal Brasileiro, o qual tipifica o crime de reduzir alguém à condição análoga à de escravo. Por meio da Portaria 540 do Ministério do Trabalho e Emprego, em 2004, houve a criação do Cadastro de Empregadores flagrados pela fiscalização com trabalhadores em condições análogas à de escravo.

1 Disponível em: <http://www.senado.gov.br/noticias/Jornal/emdiscussao/trabalho-escravo/casos-atuais-de- escravidao/ex-escravoconta-sua-historia.aspx>. Acesso em: 12.08.2015.

2 Disponível em: <http://www.planalto.gov.br/ccivil_03/leis/2003/L10.706.htm〉. Acesso em: 12.08.2015. 
Em 2005, o Ministério do Trabalho e Emprego celebrou acordo de cooperação técnica com o Ministério de Desenvolvimento Social e Combate à Fome com o objetivo de priorizar a inserção de trabalhadores resgatados no Programa Bolsa Família.

Outra ação planejada pelo Governo Brasileiro para combater a exploração de mão de obra escrava diz respeito ao $2^{\circ}$ Plano Nacional para Erradicação do Trabalho Escravo, elaborado pela CONATRAE em 2008.

Depois de quinze anos de tramitação, o Congresso Nacional promulgou, em 05.06.2014, a Emenda Constitucional 81, que alterou a redação do artigo 243 da Constituição da República, permitindo também a expropriação das propriedades rurais e urbanas onde for constatado trabalho em condições análogas à de escravo, sem qualquer indenização. Referido dispositivo constitucional já previa o confisco das glebas de qualquer região do país onde fossem localizadas culturas ilegais de plantas psicotrópicas.

Não se pode perder de vista que a nova redação dada ao dispositivo constitucional em comento contribui de modo decisivo para combater o trabalho escravo contemporâneo na medida em que atinge o bem mais precioso que o empregador escravocrata possui: sua propriedade.

Relacionadas as políticas públicas adotadas para extirpar do território nacional o trabalho escravo. Destaca-se que o principal objetivo deste artigo é sustentar a eficácia do Cadastro de Empregadores que tenham submetido trabalhadores a condição análoga à de escravo para que a sociedade e os organismos nacionais e internacionais interessados na questão possam conhecer quem são os empregadores que, em pleno século XXI, ainda exploram mão de obra escrava.

Antes disso, entretanto, apresenta-se um comparativo entre a escravidão extinta com a assinatura da Lei Áurea e a escravidão contemporânea.

\section{DIRERENÇAS E SIMILITUDE ENTRE A ANTIGA ESCRAVIDÃO E A ESCRAVIDÃO CONTEMPORÂNEA}

Engana-se quem pensa que o vergonhoso fenômeno da escravidão, que é tão antigo quanto a história da humanidade, começou no Brasil com a chegada do colonizador português. Antes deste aqui aportar, os índios já escravizavam, muito embora sem qualquer propósito comercial. Nesse sentido, a narração do capuchinho francês Claude D’ Abeville em 
1612, durante o período em que permaneceu em missão no Brasil, sobre os Tupis, uma das principais tribos indígenas brasileiras:

\begin{abstract}
Os escravos moram também com seus senhores, dentro da mesma cabana, como filhos da mesma família. Comem bem e são bem tratados. Dão-lhes por mulheres suas filhas e irmãs, as quais os tratam como maridos. Isso tudo até que lhes agrade matá-los para comê-los. Dão-lhes liberdade, entretanto, para andar à vontade, de modo a trabalharem na roça, caçarem e pescarem. Fazem, por conseguinte, o que bem entendem. As mulheres escravas são empregadas no serviço da roça e nos trabalhos domésticos, tal qual as outras mulheres, à espera, como os homens escravos, que as matem e as comam como recompensa quando se apresente a oportunidade. (D’ABBEVILLE, 1975, p. 225).
\end{abstract}

Contudo, dúvida não há, como atividade lucrativa, a exploração do trabalho escravo teve início em solo brasileiro com a chegada dos colonizadores. Naquela época, quando o direito de propriedade de um ser humano sobre outro era permitido e os escravos, ao invés de sujeitos de direito, não passavam de mercadorias, os custos para aquisição e manutenção de mão de obra escrava eram elevados.

Inversamente, na escravidão contemporânea, que é ilegal, os custos com a exploração de mão de obra escrava são baixos, uma vez que o trabalhador reduzido à condição análoga à de escravo não é objeto de compra. A pobreza e a necessidade de sobrevivência tornam legiões de trabalhadores vulneráveis, que vendem sua força de trabalho por preços vis e em condições que ferem os mais básicos direitos constitucionais e trabalhistas.

Com relação aos lucros, na antiga escravidão, o dono gastava com a manutenção dos escravos que possuía porquanto, por se tratar de um bem, o perecimento de um daqueles 'objetos' representava decréscimo do seu patrimônio. Nos dias atuais, os lucros com a exploração do trabalho escravo são altos, porque se o trabalhador adoece, sofre acidente ou morre, prontamente, é trocado por outro, sem receber qualquer direito pelos serviços prestados.

$\mathrm{Na}$ antiga escravidão, a mão de obra era escassa, pois dependia dos agentes que importavam a "mercadoria” (escravos) da África. Ao contrário, na atualidade, há um número expressivo de desempregados, sobretudo nas regiões mais pobres do Brasil, que são enganados com falsas promessas de trabalho e de uma vida melhor em locais distantes de onde vivem. 
Para o sistema escravocrata praticado antes da assinatura da Lei Áurea, a diferença étnica era relevante. Escravas eram as pessoas da raça negra trazidas da África e seus descendentes. Hoje a questão étnica não tem qualquer relevância, reduzidos à condição análoga à de escravos são os pobres e desempregados, independentemente da cor da pele.

Entretanto, um elemento característico que existia na antiga escravidão permanece igual na forma contemporânea, trata-se do uso de ameaças, violência psicológica, coerção física, punições rigorosas e até mesmos assassinatos para gerar terror e manter os trabalhadores em regime de trabalho forçado. Basta lembrar que o companheiro de fuga do trabalhador José Pereira Ferreira, o Paraná, cuja identidade permanece desconhecida, foi assassinado pelo "gato" e outros três empregados da Fazenda Espírito Santo.

Essa cruel realidade atinge, principalmente, os trabalhadores rurais, em especial aqueles do Norte e Nordeste do Brasil. No entanto, os trabalhadores urbanos das grandes cidades, inclusive crianças, adolescentes e estrangeiros, estes, sobretudo em razão da imigração irregular, não escapam de serem submetidos a condições análogas às de escravos.

Nesse sentido não destoam as palavras do Auditor Fiscal do Trabalho Renato Bignami:

\begin{abstract}
Por trás da sólida produção têxtil paulista encontra-se, muitas vezes, o trabalho precário de um trabalhador imigrante irregular. Os números exatos são desconhecidos, já que se trata de trabalho informal, essa parte desumana da economia subterrânea e não declarada. De todo modo, estima-se que dezenas de milhares de trabalhadores sul-americanos, indocumentados ou não, participam dessa cadeia produtiva e contribuem diariamente para que a moda produzida em São Paulo esteja correta e adequadamente costurada e acabada. (BIGNANI, 2011, p. 97).
\end{abstract}

As ações públicas adotadas têm dado resultados. No último dia 13 de maio, data em que a Lei Áurea, que decretou o fim da escravidão no Brasil, completou 127 anos, o Ministério do Trabalho divulgou um balanço, afirmando que "Quase 50 mil trabalhadores foram resgatados de situações análogas ao trabalho escravo nos últimos 20 anos, a maior parte em Minas Gerais [...]."3.

Apesar disso, ainda há muito a ser feito para que brasileiros e estrangeiros residentes em território nacional não sofram nas mãos de empregadores inescrupulosos que pensam apenas e tão somente em auferir grandes lucros, sem se importar com a dignidade dos trabalhadores que lhes prestam serviços.

\footnotetext{
3 Disponível em: <http://economia.uol.com.br/empregos-e-carreiras/noticias/redacao/2015/05/13/em-20-anos49-mil-trabalhadores-foram-resgatados-de-trabalho-escravo.htm>. Acesso em: 12.08.2015.
} 


\section{CONCEITO DE TRABALHO EM CONDIÇÕES ANÁlOGAS À DE ESCRAVO}

A Consolidação das Leis do Trabalho (CLT) e a legislação trabalhista a ela complementar não definem trabalho em condições análogas à de escravo. Por se tratar de um crime a sua tipificação encontra-se prevista no artigo 149 do Código Penal, com as alterações introduzidas pela Lei 10.803 , de 11.12.2003, que privilegiou a dimensão trabalhista na nova redação.

Para melhor compreensão da importância das alterações legislativas ocorrida nos últimos 127 anos, considerando como marco a Lei Áurea, que extinguiu a escravidão no Brasil, é necessário que se faça uma retrospectiva a respeito dos dispositivos legais que tratavam do trabalho escravo.

Declarada a Independência do Brasil em 1822, o país passou a sofrer forte pressão da Inglaterra, que condicionava o seu reconhecimento da independência à extinção do tráfico de escravos da África. Além disso, existia um movimento interno - os abolicionistas - que exaltava os ideais de liberdade preconizados pela Revolução Francesa de 1789.

Cedendo à pressão, o Brasil editou alguns diplomas legais, a saber: Lei 581, de 04.09.1850, conhecida como Lei Eusébio de Queiróz, que estabelecia medidas para a repressão do tráfico de escravos; Lei 2.040, de 28.09.1871, denominada Lei do Ventre Livre, diploma legal que declarava livres os filhos das escravas nascidos a partir de tal data.

Por meio da Lei 3.270, de 28.09.1885, intitulada Lei dos Sexagenários, foram libertos os escravos com mais de 60 anos de idade, e, finalmente, conforme já exposto, a Lei Áurea (Lei 3.353, de 13.05.1888), declarou extinta a escravidão no Brasil. Disso se infere que a abolição da escravatura em território nacional ocorreu por etapas e de modo muito lento.

Contudo, antes mesmo da edição da Lei Áurea, o artigo 179 do Código Criminal do Império, de 16.12.1830, prescrevia, in verbis:

Art. 179. Reduzir à escravidão a pessoa livre, que se achar em posse de sua liberdade.

Penas - de prisão por três a nove anos, e de multa correspondente à terça parte do tempo; nunca porém o tempo de prisão será menor, que o do captiveiro injusto, e mais uma terça parte.

Donde se conclui que, antes da abolição da escravidão, a legislação pátria já punia quem reduzisse ser humano livre à condição análoga à de escravo. Isso porque, já naquela época, 
a extrema pobreza, que ainda é um mal crônico em alguns rincões deste país, fazia com que seres humanos livres fossem explorados e reduzidos a condições análogas à de escravos.

O primeiro Código Penal promulgado após a proclamação da República por meio do Decreto 847 de 11.10.1890, não tratou do crime de reduzir alguém à condição análoga à de escravo, muito embora a escravidão dos negros trazidos da África tivesse sido abolida há pouco mais de dois anos.

O Código Penal de 1940, Decreto-Lei 2.848 de 07 de dezembro do referido ano, na parte especial, título I, que trata dos crimes contra a pessoa e, de modo específico, no capítulo VI, onde estão fixadas as penas para quem pratica crimes contra a liberdade individual, estabelecia, em seu artigo 149, o tipo penal "Reduzir alguém a condição análoga à de escravo: Pena - reclusão, de dois a oito anos."

No item 51 da Exposição de Motivos da Parte Especial do mencionado diploma legal, o Ministro da Justiça, à época, esclarece:

No artigo 149, é prevista uma entidade criminal ignorada do Código vigente: o fato de reduzir alguém, por qualquer meio, à condição análoga à de escravo, isto é, suprimir-lhe, de fato, o status libertatis, sujeitando-o o agente ao seu completo e discricionário poder. É o crime que os antigos chamavam plagium. Não é desconhecida a sua prática entre nós, notadamente em certos pontos remotos do nosso hinterland.

A imprecisa redação do dispositivo legal em comento dava margem a diversas interpretações, permitindo, dessa forma, a impunidade de quem cometia o crime. Dito de outro modo, o artigo 149 do Código Penal, antes das alterações produzidas pela Lei 10.803 de 11.12.2003, era um tipo penal aberto, porque o legislador limitou-se a descrever tão somente o resultado e a sanção, sem delinear a conduta típica do autor do delito, de modo que o enquadramento desta dependia da análise cognitiva do aplicador da lei, permitindo a impunidade.

Importa enfatizar que o crime tipificado no artigo 149 do Código Penal é também chamado de sujeição ou plágio, o que inclusive foi ressaltado nas Exposições de Motivos acima transcritas.

No aspecto, José Claudio Monteiro de Brito Filho, citando Pierangeli, esclarece que “A palavra plagium, etimologicamente, vem do verbo plagiare, que na Roma antiga significava a compra de um homem livre sabendo que o era, e retê-lo em servidão ou utilizálo como próprio servo". (BRITO FILHO, 2012, p. 97). 
E acrescenta de modo enfático "Não é na prática da escravidão legalizada no Brasil, então, que se devem buscar elementos para caracterizar o trabalho escravo atual, mas na antiguidade, quando era crime reduzir um homem livre à condição semelhante à de escravo." (BRITO FILHO, 2012, p. 97-98).

Atento a essas concepções, o Poder Legislativo, estimulado pelos Poderes Executivo e Judiciário, alterou a redação do artigo 149 do Código Penal, que passou a ser assim:

\footnotetext{
Art. 149. Reduzir alguém a condição análoga à de escravo, quer submetendo-o a trabalhos forçados ou a jornada exaustiva, quer sujeitando-o a condições degradantes de trabalho, quer restringindo, por qualquer meio, sua locomoção em razão de dívida contraída com o empregador ou preposto.

Pena - reclusão, de dois a oito anos, e multa, além de pena correspondente à violência.

$\S 1^{\circ}$ Nas mesmas penas incorre quem:

I - cerceia o uso de qualquer meio de transporte por parte do trabalhador, com o fito de retê-lo no local de trabalho;

II - mantém vigilância ostensiva no local de trabalho ou se apodera de documentos ou objetos pessoais do trabalhador, com o fim de retê-lo no local de trabalho.

$\S 2^{\circ}$ A pena é aumentada de metade, se o crime é cometido:

I - contra criança ou adolescente;

II - por motivo de preconceito de raça, cor, etnia, religião ou origem.
}

Disso se infere que os modos típicos de execução do trabalho escravo referem-se a 04 (quatro) situações, a saber: 1) trabalho forçado; 2) jornada exaustiva; 3) condições degradantes de trabalho; 4) restrição de locomoção por dívida contraída com o empregador ou preposto.

Dois desses modos têm por objetivo proteger a liberdade do trabalhador, quando se referem ao trabalho forçado e restrição da liberdade de ir e vir decorrente de dívida, e os outros dois visam garantir condições de trabalho salubres, quando mencionam jornada exaustiva e condições degradantes de trabalho.

Desse modo, a partir da nova redação do dispositivo legal em tela, o crime de redução à condição análoga à de escravo não ocorre apenas quando a liberdade da vítima é diretamente tolhida. Pelo contrário, nas hipóteses de jornada exaustiva e condições degradantes de trabalho, ainda que não exista supressão da liberdade do trabalhador, o crime se caracteriza.

Acrescentado pela Lei 10.803/2003 o $§ 1^{\circ}$ do artigo 149 do Código Penal introduziu no ordenamento jurídico três condutas típicas de trabalho contemporâneo. Elas se configuram quando o empregador - ou seus prepostos - "cerceia o uso de qualquer meio de transporte por parte do trabalhador, com o fim de retê-lo no local de trabalho", ou "mantém vigilância 
ostensiva no local de trabalho", ou, ainda, "se apodera de documentos ou objetos pessoais do trabalhador, com o fim de retê-lo no local de trabalho".

Como se vê, a alteração do artigo 149 do Código Penal ampliou o espectro de consideração do bem jurídico tutelado, porque, sem olvidar da liberdade, levou em conta um atributo maior do ser humano, que é a sua dignidade, eleita como um dos fundamentos da República, conforme inciso III do artigo $1^{\circ}$ da Carta Magna de 1988.

Nas palavras de Ingo Wolfgang Sarlet:

Dignidade é a qualidade intrínseca e distintiva de cada ser humano que o faz merecedor do mesmo respeito e consideração por parte do Estado e da comunidade, implicando, neste sentido, um complexo de direitos e deveres fundamentais que assegurem a pessoa tanto contra todo e qualquer ato de cunho degradante e desumano, como venham a lhe garantir as condições existenciais mínimas para uma vida saudável, além de propiciar e promover sua participação ativa e co-responsável nos destinos da própria existência e da vida em comunhão com os demais seres humanos. (SARLET, 2008, p. 66).

Conclui-se, assim, que a dignidade da pessoa humana é intangível, constituindo-se pilar de todos os direitos fundamentais expressos na Carta Magna de 1988. Desse modo, o trabalhador não pode ser visto como uma mercadoria barata, utilizado apenas como mais um instrumento da produção, necessário ao empregador somente para aumentar os lucros do empreendimento.

\section{O CADASTRO DE EMPREGADORES QUE TENHAM MANTIDO TRABALHADORES EM CONDIÇÕES ANÁlOGAS À DE ESCRAVO ("LISTA SUJA")}

Para combater o trabalho em condição análoga à de escravo várias políticas públicas vem sendo desenvolvidas. Dentre elas a que busca reprimir o trabalho escravo contemporâneo é realizada pelos Grupos Especiais de Fiscalização Móvel (GEFM), criados em 1995, compostos por Auditores Fiscais do Trabalho, com a presença de membros do Ministério Público do Trabalho, da Polícia Federal e, em alguns casos, da Polícia Rodoviária Federal.

Essa composição interinstitucional objetiva dificultar ingerências e corrupção, uma vez que os integrantes dos diversos órgãos sempre atuam juntos. Além disso, com essa composição, os GEFM's reúnem as competências necessárias para que a fiscalização 
realizada acarrete para o infrator consequências nas esferas administrativa, trabalhista e criminal.

Realizada a inspeção e constatada a existência de trabalho análogo ao de escravo é lavrado um Auto de Infração que dá origem a um processo administrativo. Concluído o processo a Secretaria de Inspeção do Trabalho (SIT) faz uma nova análise para verificar se, de fato, trata-se de um caso de trabalho escravo contemporâneo. Em caso afirmativo, os dados do empregador, pessoa física ou jurídica, são incluídos no Cadastro de Empregadores que tenham mantido trabalhadores em condições análogas à de escravo, criado em 2004.

A inserção do nome dos infratores no aludido cadastro traz diversas consequências prejudiciais para os empregadores que exploram mão de obra escrava. Além da visibilidade para a sociedade, eles ficam impedidos de obter empréstimos em bancos públicos e têm suas relações comerciais cortadas com as empresas que assinaram o Pacto Nacional pela Erradicação do Trabalho Escravo.

A "lista suja”, denominação popular do cadastro de pessoas físicas e jurídicas autuadas por exploração do trabalho escravo, surgiu quando, o Ministro do Trabalho e Emprego, no uso da atribuição que lhe confere o artigo 87, parágrafo único, inciso II, da Carta Cidadã de 1988, determinou, por meio da Portaria n. 1.234 de 17.11.2003, o encaminhamento semestral da relação de empregadores que submetem trabalhadores a formas degradantes de trabalho ou os mantêm em condições análogas à de escravo aos seguintes órgãos: Secretaria Especial de Direitos Humanos, Ministério do Meio Ambiente, Ministério do Desenvolvimento Agrário, Ministério da Integração Nacional e Ministério da Fazenda, com a finalidade de subsidiar ações no âmbito de competência de tais órgãos, sendo que, no caso do Ministério do Meio Ambiente, a relação somente deveria ser encaminhada quando fossem relatados por Auditores Fiscais do Trabalho indícios de degradação ambiental.

Por sua vez, o Ministro da Integração Nacional, por intermédio do artigo $1^{\circ}$ da Portaria n. 1.150 de 18.11.2003, determina:

[...] ao Departamento de Gestão dos Fundos de Desenvolvimento Regional da Secretaria de Políticas de Desenvolvimento Regional do Ministério que encaminhe, semestralmente, aos bancos administradores dos Fundos Constitucionais de Financiamento, idem com relação aos Fundos Regionais, relação de empregadores e de propriedades rurais, que submetam trabalhadores a formas degradantes de trabalho ou que os mantenham em condições análogas ao de trabalho escravo, cujas autuações com decisão administrativa são de procedência definitiva, publicada pelo Ministério do Trabalho e Emprego, para as providências cabíveis. 
$\mathrm{O}$ artigo $2^{\circ}$ da mencionada portaria, por seu turno, recomenda aos agentes financeiros que se abstenham de conceder financiamentos ou qualquer tipo de assistência com recursos sob supervisão do Ministério da Integração Nacional para as pessoas físicas e jurídicas que venham a figurar no Cadastro de Empregadores que tenham mantido trabalhadores em condições análogas à de escravo.

Entretanto, em pouco tempo, o Poder Executivo concluiu que o procedimento estabelecido na Portaria n. 1.234 do Ministério do Trabalho e Emprego ocasionava excesso de burocracia e, na prática, não estava surtindo qualquer efeito, porque tudo acontecia no âmbito da administração, inexistia visibilidade, transparência. Noutros termos, a sociedade não tinha conhecimento acerca das ações públicas executadas para acabar com a escravidão contemporânea.

Assim, por meio da Portaria n. 540 do Ministério do Trabalho e Emprego, de 15.10.2004, que expressamente revogou a Portaria n. 1.234/2003, foi criado o Cadastro de Empregadores que tenham mantido trabalhadores em condições análogas à de escravo, na forma como ele é hoje.

Em 16.11.2004, pouco mais de um mês da entrada em vigor da Portaria n. 540 do Ministério do Trabalho e Emprego, a Confederação da Agricultura e Pecuária do Brasil (CNA), representante da classe agropecuarista brasileira, ajuizou, no Supremo Tribunal Federal, a Ação Direta de Inconstitucionalidade (ADI) n. 3347/DF, com pedido de medida cautelar, argumentando que o citado ato normativo viola o disposto no inciso I do artigo 22 da Constituição da República, que atribui competência privativa à União para legislar sobre direito do trabalho.

Também foi aduzido na referida ADI que a Portaria n. 540 do Ministério do Trabalho e Emprego ofende o direito de propriedade, o princípio da presunção de inocência, do devido processo legal e da ampla defesa e contraditório.

Transcorridos quase oito anos, em abril de 2012 o Ministro Relator Ayres Britto julgou extinta a mencionada ação direta de inconstitucionalidade, por perda de objeto, em razão da publicação da Portaria Interministerial MTE/SDH n. 2, de 12.05.2011, do Ministério do Trabalho e Emprego e da Secretaria de Direitos Humanos da Presidência da República, que revogou expressamente a Portaria MTE n. 540.

A história se repete e, em 24.04.2014, a Confederação Nacional de Agricultura e Pecuária do Brasil (CNA), propôs a Ação Direta de Inconstitucionalidade n. 5115/DF, com 
requerimento de medida cautelar, contra a Portaria Interministerial n. 2, de 12.05.2011, editada pelo Ministro do Trabalho e Emprego e pela Ministra Chefe da Secretaria de Direitos Humanos da Presidência da República. Na mencionada ação, que ainda encontra-se em trâmite, foi adotado o rito do artigo 12 da Lei 9.868/1999, no entanto, não foi concedida a medida cautelar.

Por sua vez, em 22.12.2014, a Associação Brasileira de Incorporadoras Imobiliárias - ABRAINC ajuizou a Ação Direta de Inconstitucionalidade n. 5209/DF, com pedido de medida cautelar, requerendo a declaração de inconstitucionalidade da Portaria Ministerial n.

2, de 12.05.2011, do Ministério do Trabalho e Emprego e da Secretaria de Direitos Humanos da Presidência da República e, em razão do efeito repristinatório, também da Portaria n. 540 do Ministério do Trabalho e Emprego.

A ABRAINC alega ofensa aos artigos 87, inciso II; e 186, incisos III e IV, ambos da Constituição da República, bem como violação aos princípios da separação dos poderes, da reserva legal e da presunção de inocência.

O presidente do Supremo Tribunal Federal (STF), Ministro Ricardo Lewandowski, em 23.12.2014, deferiu, ad referendum do Plenário do STF, o pedido de medida liminar formulado na inicial da ADI n. 5209/DF, suspendendo a eficácia das duas portarias citadas acima. Entendeu o magistrado que inexiste lei formal que respalde a edição da Portaria n. 2/2011.

Três após a decisão do STF, a Portaria Interministerial MTE/SDH n. 2/2011 foi revogada pela Portaria Interministerial MTE/SDH n. 2, de 31.03.2015, do Ministério do Trabalho e Emprego e da Secretaria de Direitos Humanos da Presidência da República.

A atual portaria interministerial, que enuncia regras sobre o Cadastro de Empregadores que tenham submetido trabalhadores a condição análoga à de escravo e revoga a Portaria Interministerial MTE/SDH n. 2/2011, com base no princípio da transparência, segundo o qual a Administração Pública deve divulgar informações para que a sociedade possa tomar conhecimento das ações governamentais desenvolvidas, tem por fundamento o disposto nos artigos $3^{\circ}$, incisos I e II, e $7^{\circ}$, incisos VII, alínea b, da Lei 12.527, de 18.11.2011 (Lei de Acesso à Informação).

Citado ato normativo tem por fundamento também a Convenção 29 da OIT, promulgada pelo Decreto 41.721, de 25.06.1957, a Convenção 105 da OIT, promulgada pelo Decreto 58.822, de 14.07.1966, a Convenção sobre a Escravatura de Genebra, promulgada 
pelo Decreto 58.563, de 01.06.1966, e a Convenção Americana de Direitos Humanos, promulgada pelo Decreto 678, de 06.11.1992.

Com a edição da Portaria Interministerial MTE/SDH n. 2/2015 as Ações Diretas de Inconstitucionalidade propostas pela CNA (5115/DF) e pela ABRAINC (5209/DF) perderam o objeto. Isso porque, conforme decidido nos autos da Ação Direta de Inconstitucionalidade n. 3347/DF, a revogação ou perda de vigência da norma impugnada constitui causa superveniente de perda de objeto da ação, com o consequente desaparecimento do interesse de agir do autor.

Contudo, ainda que assim não fosse, não seria possível acolher a pretensão formulada nas aludidas ações diretas de inconstitucionalidade, porque a Portaria Interministerial MTE/SDH n. 2, de 12.05.2011, não padecia de qualquer inconstitucionalidade, uma vez que sua edição observou os princípios constitucionais e as normas legais que regem a regem a matéria.

Na forma do artigo 87, parágrafo único, inciso II, da Constituição Federal, o Ministro do Trabalho e Emprego detém competência para a expedição de atos administrativos necessários para o cumprimento dos fins que competem ao respectivo Ministério. Essa competência não se confunde com competência legislativa, de modo que não se pode falar em ofensa aos princípios da reserva legal e da legalidade, previstos no artigo $5^{\circ}$, incisos II e XXIX, da Constituição da República.

Como destaca João Humberto Cesário, a portaria em questão encontra respaldo nos seguintes dispositivos constitucionais e infraconstitucional:

[...] no art. 21, XXIX, da CRFB, que dita competir à União organizar, manter e executar a inspeção do trabalho; no art. 87, I, da CRFB, que diz competir ao Ministro de Estado, exercer a orientação, coordenação e supervisão dos órgãos e entidades da administração federal na área de sua competência; bem como no art. 913 da CLT, a dizer que o Ministro do Trabalho expedirá instruções, quadros, tabelas e modelos que se tornarem necessários à execução da CLT. (CESÁRIO, 2011, p. 161).

Também não se pode falar que o ato normativo do Ministério do Trabalho e Emprego que estabelece a "lista suja" viola o direito de propriedade, assegurado pelo artigo $5^{\circ}$, inciso XXII, da Carta Magna de 1988, uma vez que o inciso seguinte (XXIII) prevê que "a propriedade atenderá a sua função social". 
Por sua vez, o artigo 184 da Constituição da República, determina a desapropriação do imóvel rural que não esteja cumprindo a sua função social. Os empregadores rurais que utilizam mão de obra semelhante à escrava descumprem o disposto nos incisos III e IV do artigo 186, também da Constituição, os quais dispõem que a função social da propriedade rural é cumprida com a "observância das disposições que regulam as relações de trabalho" e a “exploração que favoreça o bem-estar dos proprietários e dos trabalhadores".

Nesse sentido, o autor citado anteriormente enfatiza:

\begin{abstract}
Ora, se em última instância é legítimo à União, nos termos do $§ 2^{\circ}$ do art. 184 da CRFB, editar um decreto declarando o imóvel como de interesse social, para fins de instauração do procedimento de desapropriação, por certo será muito mais lícito que, por via dos Ministérios competentes, publique portarias que visem coibir a existência da repugnante prática de servidão contemporânea, com expressa vedação ao financiamento público da atividade privada incapaz de cumprir sua função social. (CESÁRIO, 2011, p. 159).
\end{abstract}

Quanto à suposta violação ao princípio da presunção de inocência, previsto no inciso LVII do artigo $5^{\circ}$ da Constituição da República, importa frisar que tal dispositivo aplica-se tão somente no âmbito penal. Por sua vez, a inclusão do nome da pessoa física ou jurídica no Cadastro de Empregadores que tenham mantido trabalhadores em condições análogas à de escravo decorre da atuação da fiscalização do Ministério do Trabalho e Emprego, no âmbito administrativo de sua competência.

A inserção dos nomes dos empregadores que exploram mão de obra escrava na "lista suja" também não fere os princípios da ampla defesa, do contraditório e do devido processo legal. Tal inclusão limita-se a dar publicidade à sociedade acerca do resultado da fiscalização realizada pelo Ministério do Trabalho e Emprego em que restou constatada da existência de trabalho escravo contemporâneo. Ademais, o nome do empregador somente é incluído no Cadastro após decisão administrativa definitiva irrecorrível.

Lado outro, se o empregador recorre ao Poder Judiciário e obtém decisão favorável, o Ministério do Trabalho e Emprego, em cumprimento ao julgado, procede à imediata exclusão do nome do Cadastro e assim permanece até eventual suspensão da medida liminar ou decisão de mérito.

Como se vê, mesmo que a Portaria Interministerial MTE/SDH n. 2, de 12.05.2011, não tivesse sido revogada pela Portaria Interministerial MTE/SDH n. 2, de 31.03.2015, as ações diretas de inconstitucionalidades ajuizadas pela CNA e pela ABRAINC, que tramitam no 
Supremo Tribunal Federal, estavam fadadas ao insucesso, uma vez que aquele ato normativo, que não mais vigora, observou os princípios da ampla defesa, do contraditório, do devido processo legal e não infringiu o direito de propriedade.

O duro golpe aplicado nos empregadores autuados por exploração de mão de obra escrava está relacionado ao fato de ficar impedido de conseguir empréstimos em bancos públicos, conforme recomendada o artigo $2^{\circ}$ da Portaria n. 1.150, de 18.11.2003, do Ministério da Integração Nacional.

Entretanto, no aspecto, perspicaz a observação de João Humberto Cesário:

Com efeito, é absolutamente válido que a União, por via da atuação dos Ministros de Estado, se valha de critérios administrativos visando financiar a atividade produtiva séria e lícita, em detrimento daquela que, na ganância por lucros desmedidos, transpõe as raias da criminalidade, desprezando os fundamentos que se constituem no centro vital da Constituição da República Federativa do Brasil.

Aliás, decididamente não parece razoável que fazendeiros sérios, que observam rigorosamente a legislação trabalhista, devam disputar créditos públicos em pé de igualdade com aqueles que maltratam a dignidade do ser humano, sendo inquebrantável obrigação do Poder Executivo tratá-los de modo desigual, já que, como é curial, o princípio da isonomia, direito e garantia fundamental da sociedade (art. $5^{\circ}$, caput, da CRFB), consiste em tratar os iguais de maneira igual e os desiguais de modo desigual, na exata medida de suas desigualdades. (CESÁRIO, 2011, p. 160-161).

Noutro viés, ressalte-se que a sustentabilidade das práticas adotadas pelo Ministério do Trabalho e Emprego e pelos demais agentes envolvidos (Ministério Público do Trabalho, Polícia Federal, Polícia Rodoviária Federal e Poder Judiciário) no combate e erradicação do trabalho escravo contemporâneo depende de constante aperfeiçoamento, uma vez que os empregadores vêm encontrando maneira de driblar a fiscalização.

Assim, a revogação da Portaria Interministerial MTE/SDH n. 2, de 12.05.2011, por intermédio da Portaria Interministerial MTE/SDH n. 2, de 31.03.2015, constitui mero aprimoramento de ato normativo, mesmo porque, quando a primeira foi editada, ainda não tinha entrado em vigor a Lei de Acesso à Informação, diploma legal que trata de um importante instrumento de consolidação do Estado Democrático de Direito, a transparência das ações do governo.

Lado outro, para que a exploração de mão de obra escrava tenha fim é importante que a vulnerabilidade do trabalhador seja gradualmente reduzida. Assim, a sustentabilidade da ação de resgate do trabalhador reduzido à condição análoga à de escravo, advinda da fiscalização realizada pelo Grupo Especial de Fiscalização Móvel (GEFM), depende do fortalecimento dos 
programas que têm por objetivo a reinserção do trabalhador regatado e a geração de emprego nas regiões onde os níveis de pobreza são mais acentuados, porque, do contrário, sem alternativa para ganhar o seu sustento, o trabalhador volta à condição de escravo contemporâneo novamente.

\section{CONCLUSÃO}

O Estado brasileiro, desde 1995, quando celebrou Acordo de Solução Amistosa com a Comissão Interamericana de Direitos Humanos, órgão da Organização dos Estados Americanos, trava uma árdua batalha para erradicar o trabalho escravo contemporâneo, conduta ilícita que viola a dignidade da pessoa humana e os valores sociais do trabalho e da livre iniciativa, princípios previstos na Carta Magna de 1988, pilares do Estado Democrático de Direito.

Dentre as ações colocadas em prática para combater e extirpar o trabalho em condições análogas à de escravo, chaga social que macula a imagem do país, o Governo brasileiro, por intermédio do Ministério do Trabalho e Emprego e Emprego, instituiu o Grupo Executivo de Repressão ao Trabalho Forçado (GERTRAF), posteriormente substituído pela Comissão Nacional de Erradicação do Trabalho Escravo (CONATRAE), cuja principal função é monitorar a execução do Plano Nacional para Erradicação do Trabalho Escravo, que já se encontra em sua segunda edição.

Em paralelo também foi criado o Grupo Especial de Fiscalização Móvel (GEFM), composto por Auditores Fiscais do Trabalho, com a presença de membros do Ministério Público do Trabalho, da Polícia Federal e, em certos casos, da Polícia Rodoviária Federal, que fiscalizam os locais de trabalho e, quando há a constatação de exploração de mão de obra escrava, o empregador, pessoa física ou jurídica, é autuado.

Lavrado o auto de infração, que origina um processo administrativo, onde são observados os princípios da ampla defesa, do contraditório e do devido processo legal, após decisão administrativa definitiva irrecorrível não favorável ao empregador, o nome deste é incluído no Cadastro de Empregador que tenham mantido trabalhadores em condições análogas à de escravo, popularmente conhecido como "lista suja", criado pela Portaria MTE n. 540/2004, revogada pela Portaria Interministerial MTE/SDH n. 2/2011. 
Nada obstante duas entidades patronais tenham ajuizado no Supremo Tribunal Federal medidas judiciais com o fito de obter a declaração de inconstitucionalidade da Portaria Interministerial MTE/SDH n. 2/2011, certo é que este ato normativo foi revogado pela Portaria Interministerial MTE/SDH n. 2/2015, editada com fulcro na Lei de Acesso à Informação, que garante à sociedade o direito de ter conhecimento acerca das ações colocadas em prática pelo governo.

As sucessivas revogações das portarias que determinam a inclusão dos nomes dos empregadores flagrados explorando trabalhadores em condições análogas à de escravo constituir mero aprimoramento de ato normativo, uma vez que a sustentabilidade das práticas adotadas para combater o trabalho escravo contemporâneo depende de constante aperfeiçoamento.

Entretanto, para que o trabalho análogo ao de escravo seja extirpado do território nacional, faz-se necessário que, gradualmente, a vulnerabilidade do trabalhador seja reduzida. Para isso, é preciso intensificar a fiscalização, fortalecer programas de reinserção do trabalhador resgatado e promover a geração de emprego nas regiões mais pobres do país, para que o ser humano não venha a ser refém das próprias necessidades e tenha preservada a sua dignidade.

\section{REFERÊNCIAS}

BASTOS, Fernanda Soares. O trabalho escravo contemporâneo no Brasil e a evolução das políticas de proteção aos trabalhadores. Revista do Tribunal Regional do Trabalho da $3^{a}$ Região. Belo Horizonte, v. 57, n. 87/88, p. 117-128, jan./dez. 2013.

BIGNAMI, Renato. Trabalho Escravo Contemporâneo: o sweanting system no contexto brasileiro como expressão do trabalho forçado urbano. In: NOCCHI, Andrea Saint Pastous (coord.). Trabalho escravo contemporâneo: o desafio de superar a negação. 2. ed. São Paulo: LTr, 2011, p. 76-112.

BRASIL. Lei 581, de 4 de setembro de 1850. Estabelece medidas para a repressão do tráfico de africanos no Império. Lei Eusébio de Queiroz. Disponível em: <http://www.planalto.gov.br/ccivil_03/leis/LIM/LIM581.htm>. Acesso em: 13 ago. 2015.

BRASIL. Lei 2.040, de 28 de setembro de 1871. Lei do Ventre Livre. Disponível em: <http://www2.senado.leg.br/bdsf/item/id/496715>. Acesso em: 13 ago. 2015. 
BRASIL. Lei 3.278, de 28 de setembro de 1885. Lei dos Sexagenários. Disponível em: <http://www2.senado.leg.br/bdsf/item/id/181850>. Acesso em: 13 ago. 2015.

BRASIL. Lei 3.353, de 13 de maio de 1888. Lei Áurea. Declara extinta a escravidão no Brasil. Disponível em: <http://www.planalto.gov.br/ccivil_03/leis/LIM/LIM3353.htm>. Acesso em: 13 ago. 2015.

BRASIL. Lei de 16 de dezembro de 1830. Código Criminal do Império. Disponível em: <http://www.planalto.gov.br/ccivil_03/leis/LIM/LIM-16-12-1830.htm>. Acesso em: 13 ago. 2015.

BRASIL. Decreto 847, de 11 de outubro de 1890. Promulga o Código Penal. Disponível em: <http://www2.camara.leg.br/legin/fed/decret/1824-1899/decreto-847-11-outubro-1890503086-norma-pe.html>. Acesso em: 15 ago. 2015.

BRASIL. Decreto-Lei 2.848, de 7 de dezembro de 1940. Código Penal. Disponível em: <http://www2.camara.leg.br/legin/fed/declei/1940-1949/decreto-lei-2848-7-dezembro-1940412868-publicacaooriginal-1-pe.html>. Acesso em: 15 ago. 2015.

BRASIL. Portaria 1.234, de 17 de novembro de 2003, do Ministério do Trabalho e Emprego. Estabelece procedimentos para encaminhamento de informações sobre inspeções do trabalho a outros órgãos. Disponível em: <http://portal.mte.gov.br/legislacao/portaria-n-1-234-de-1711-2003.htm>. Acesso em: 16 ago. 2015.

BRASIL. Portaria 1.150, de 18 de novembro de 2003, do Ministério da Integração Nacional. Disponível em: <http://www.mi.gov.br/c/document_library/get_file?uuid=b9f0a700-687a47e3-9c1c-4d418f9e6cf8\&groupId=407753>. Acesso em: 16 ago. 2015.

BRASIL. Portaria 540, de 15 de outubro de 2004, do Ministério do Trabalho e Emprego. Cria, no âmbito do Ministério do Trabalho e Emprego - MTE, o Cadastro de Empregadores que tenham mantido trabalhadores em condições análogas à de escravo. Disponível em: <http://portal.mte.gov.br/data/files/FF8080812BE914E6012BF2B6EE26648F/p_20041015_5 40.pdf>. Acesso em: 16 ago. 2015.

BRASIL. Supremo Tribunal Federal. Ação Direta de Inconstitucionalidade 3347/DF. Requerente: Confederação da Agricultura e Pecuária do Brasil. Relator Ministro Ayres Britto. Decisão Monocrática. Divulgada no Diário da Justiça Eletrônico n. 70, de 11 de abril de 2012. Disponível em: <http://www.stf.jus.br/portal/diarioJustica/verDiarioProcesso.asp?numDj=70\&dataPublicacao $\mathrm{Dj}=11 / 04 / 2012 \&$ incidente $=2255798 \& \operatorname{codCapitulo}=6 \&$ numMateria $=46 \& \operatorname{codMateria}=2>$. Acesso em: 16 ago. 2015.

BRITO FILHO, José Claudio Monteiro de. Dignidade da pessoa humana como fundamento para o combate ao trabalho em condições análogas à de escravo: a contribuição da $1^{\text {a }}$ turma do 
Tribunal Superior do Trabalho no processo TST-RR-178000-13.2003.5.03.0117. Revista TST, Brasília, v. 78, n. 3, jul./set. 2012.

CESÁRIO, João Humberto. O Cadastro de Empregadores que tenham mantido trabalhadores em condições análogas à de escravo como instrumento de afirmação da cidadania: questões constitucionais e processuais (à luz da nova lei do mandado de segurança). In: NOCCHI, Andrea Saint Pastous (coord.). Trabalho escravo contemporâneo: o desafio de superar a negação. 2. ed. São Paulo: LTr, 2011, p. 147-165.

D’ABBEVILLE, Claude. História da missão dos padres capuchinhos na Ilha do Maranhão e terras circunvizinhas. Tradução Sérgio Milliet. Belo Horizonte: Itatiaia, 1975.

FIRME, Telma Barros Penna. O caso José Pereira: responsabilização do Brasil por violação de direitos humanos em relação ao trabalho escravo. Revista LTr: Legislação do Trabalho. São Paulo, v. 75, n. 3, p. 349-357, mar. 2011.

GONÇALVES FILHO, Olival Rodrigues. O trabalho escravo contemporâneo e os mecanismos de sua erradicação. Revista do Tribunal Regional do Trabalho da $18^{a}$ Região. Goiânia, v. 15, p. 379-395, jan./dez. 2012.

MELO, Guilherme Orlando Anchieta; LORENTZ, Lutiana Nacur. Uma abordagem interdisciplinar do trabalho análogo ao de escravo nas clivagens: trabalho forçado, degradante e desumano. Revista do Tribunal Regional do Trabalho da $3^{a}$ Região. Belo Horizonte, v. 54, n. 84, p. 263-288, jul./dez. 2011.

MIRAGLIA, Lívia Mendes Moreira. Trabalho escravo contemporâneo: conceituação à luz do princípio da dignidade da pessoa. São Paulo: LTr, 2011.

NEVES, Débora Maria Ribeiro. Consequências da promulgação da EC 81/2014: retrocesso no combate ao trabalho escravo. Revista de Direito do Trabalho. São Paulo, v. 40, n. 158, p. 61-72, jul./ago. 2014.

PEREIRA, Cícero Rufino. O "velho" trabalho escravo e as perspectivas do tema a partir da EC 81/2014. Revista de Direito do Trabalho. São Paulo, v. 40, n. 159, p. 13-37, set./out. 2014.

PRONER, André Luiz. Neoescravismo: análise jurídica das relações de trabalho. Curitiba: Juruá, 2010.

ROJAS, Ana Paula Freira; GÓES, Maurício de Carvalho. O trabalho escravo como forma de violação aos direitos humanos e à dignidade do trabalhador. Justiça do Trabalho: Caderno de direito previdenciário. Porto Alegre, v. 30, n. 356, p. 44-66, ago. 2013. 
SALVATTI, Ideli. O Estado no combate ao trabalho escravo. Revista do Direito Trabalhista - RDT. Brasília, v. 20, n. 7, p. 32-33, jul. 2014.

SILVA, José Afonso da. Curso de direito constitucional positivo. 37. ed., rev. e atual. São Paulo: Malheiros, 2014.

SIQUEIRA, Túlio Manoel Leles de. O trabalho escravo perdura no Brasil do século XXI. Revista do Tribunal Regional do Trabalho da $3^{a}$ Região. Belo Horizonte, v. 52, n. 82, p. 127147, jul./dez.2010.

VILLELLA, Fábio Goulart. O princípio constitucional da dignidade da pessoa humana no direito do trabalho. Revista LTr: Legislação do Trabalho. São Paulo, v. 74, n. 01, p. 81-88, jan. 2010.

ZAINAGHI, Domingos Sávio. A proibição do trabalho escravo ou forçado. Revista de Direito do Trabalho. São Paulo, v. 38, n. 147, p. 353-362, jul./set.2012. 